\title{
Socioeconomic Disparities in Oral Health Related Quality of Life of Schoolchildren: A Cross-Sectional Study
}

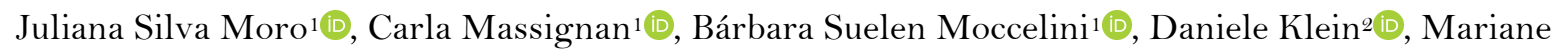 \\ Cardoso $^{1}$, Michele Bolan ${ }^{1}$
}

${ }^{1}$ Department of Dentistry, Health Science Center, Federal University of Santa Catarina, Florianópolis, SC, Brazil. ${ }^{2}$ Private Practice, São Miguel do Oeste, SC, Brazil.

Author to whom correspondence should be addressed: Juliana Moro, Departamento de Odontologia, Centro de Ciências da Saúde, Universidade Federal de Santa Catarina, Campus Trindade, Rua Delfino Conti, S/N, Florianópolis, SC, Brazil. 88040-370. Phone: +55 55991269721. E-mail: juliana.moroo@hotmail.com.

Academic Editors: Alessandro Leite Cavalcanti and Wilton Wilney Nascimento Padilha

Received: 05 February 2020 / Accepted: 13 April 2020 / Published: 08 June 2020

How to cite this article: Moro JS, Massignan C, Moccelini BS, Klein D, Cardoso M, Bolan M. Socioeconomic disparities in oral health related quality of life of schoolchildren: a cross-sectional study. Pesqui Bras Odontopediatria Clín Integr. 2020; 20:e0009. https://doi.org/10.1590/pboci.2020.101

\begin{abstract}
Objective: To analyze whether demographic and socioeconomic factors can influence the OHRQoL in schoolchildren. Material and Methods: A cross-sectional study using a representative sample of 1137 children aged 8-10 years, enrolled in public schools in Florianópolis, Brazil, was conducted. Children answered the Brazilian version of the Child Perceptions Questionnaire (CPQ8-10) quality of life questionnaire and their parents responded to socioeconomic and demographic questions. Logistic regression models were used to analyze the data. Results: Higher probability of presenting a negative impact on the OHRQoL was observed in children whose skin color was non-white (OR 1.46, 95\% CI 1.04-1.69) and female (OR 1.33, 95\% CI 1.04-1.69). Children in whom the head of the family had years of schooling 9-11 $(\mathrm{p}=0.001), 5-8(\mathrm{p}=0.005)$ and $\leq 4(\mathrm{p}=0.000)$ were more likely to have a negative impact on the OHRQoL. CPQ8-10 domains evaluation showed that variables education, gender, skin color, and age were associated with a negative impact on OHRQoL $(\mathrm{p} \leq 0.05)$. Conclusion: The educational level of the head of the family and the demographic characteristics of the children are associated with a negative impact on the OHRQoL.

Keywords: Children; Epidemiology; Socioeconomic Factors; Oral Health; Quality of Life.
\end{abstract}




\section{Introduction}

The oral health-related quality of life (OHRQoL) is a comprehensive concept that reflects the psychological, functional and social aspects of a person [1]. In pediatric dentistry, this concept includes characteristics related to parents, such as socioeconomic status and dental anxiety that of the child, such as infantile dental anxiety and complications associated with oral health [2]. The OHRQoL measurements, concurrently with clinical parameters, have often been applied to measure the impact that oral diseases and their consequences have on the population. Besides, such measurements allow the identification of the patient's concerns and compare with the oral health changes among subjects [3,4].

The literature has shown that oral health conditions such as dental caries, dental pain and malocclusion interfere with the children's daily activities, influencing negatively on the quality of life [5-7]. In addition to clinical factors, the context in which the subject is inserted and its social determinants should be evaluated to better understand the oral health-disease process [8-10]. Children belonging to socioeconomically disadvantaged groups tend to have a higher prevalence of dental caries and oral diseases to increasing OHRQoL inequalities [8].

In Brazil, inequalities involving health care are still remarkable among the socially disadvantaged population [8], as health conditions and diseases follow the social position of the subject [11]. Studies have shown that socioeconomic and behavioral conditions in childhood affect the overall health and oral health in adulthood [12-14]. Therefore, epidemiological information about oral health and its impact on the quality of life of a subject can be an efficient indicator of social inequalities in childhood, also assisting in designing specific public policies for prevention and health promotion to reduce discrepancies in short and long terms $[11,15]$. Also, few studies carry out model adjustment tests to verify whether the proposed model explains what is observed, as performed in the present study.

The current research study aimed at analyzing the influence of demographic and socioeconomic characteristics on the OHRQoL in 8 to 10-year old children. This study hypothesizes that children belonging to lower socioeconomic levels report a negative impact on the OHRQoL several domains.

\section{Material and Methods}

Study Design

This is a cross-sectional study that was conducted in public elementary schools in the city of Florianópolis, Santa Catarina, Brazil. Florianópolis is among the cities with the highest Human Development Index (HDI) in the country (0.847) [16]. The study is reported following the Strengthening the Reporting of Observational Studies in Epidemiology (STROBE) guidelines. Data were collected from September to December 2015.

\section{Sampling}

In this research study, the sample comprised 8 to 10-year old children and their parents or guardians. The representative sampling was set up in two stages; in the first stage, public schools were drawn and, in the second stage, the classrooms were drawn. The sample size was calculated according to the prevalence of the negative impact on the quality of life related to oral health of $50 \%$, confidence interval of $95 \%$ and standard error of 4\%. A minimum sample size of 613 participants was required. A design effect of 1.5 and a percentage of $30 \%$ was applied to compensate for possible losses and the final estimated sample was 1193 school children $[17]$. 
The research inclusion criteria were 8 to 10-year old children, regularly enrolled in public schools, literate and whose parents or guardians agreed with the terms of consent of the study. Children who were taking medication affecting the central nervous system, illiterate and undergoing orthodontic treatment were excluded from the sample.

\section{Data Collection}

The outcome evaluation for the oral health-related quality of life, the $\mathrm{CPQ}_{8-10}$ questionnaire, validated in Portuguese, was applied [18]. The questionnaire consisted of 29 multiple-choice questions divided in four domains. Questions 1 and 2 refer to children's gender and age and questions 3 and 4 refer to children's oral health and well-being. The remaining questions (5 to 29) were divided into the following domains: oral symptoms (questions 5 to 9), functional limitations (questions 10 to 14), emotional well-being (questions 15 to 19 ) and social well-being (questions 20 to 29). Possible answers and scores vary as follows: "Never" =0; "Once or twice" =1; "Sometimes" =2; "Often" =3; "Every day or almost every day" =4. The CPQ ${ }_{8-10}$ overall score can range from 0 to 100 points, for the oral symptoms o to 20 , functional limitations 0 to 20 , emotional well-being 0 to 20 , and social well-being o to 40 . In the questionnaire, the answers were dichotomized into "No negative impact" and "Negative impact" for the quality of life related to oral health, considering the $\mathrm{CPQ}_{8-10}$ median total scores (12 points) and their respective domains [19].

A self-reported and structured questionnaire was sent to caregivers, which included sample characteristics such as: which included sample characteristics such as: children gender (female or male), children skin color (white or non-white) [20], age (8,9 and 10-year old children), general children health (very good/good or regular/poor) and school shift (morning or afternoon). Socioeconomic status was assessed applying criteria according to the Brazilian Association of Research Companies, including the head of the household education level categorized as $\geq 12,9-11,5-8$ and $\leq 4$ years of study [21], family income dichotomized to $>2$ minimal wages, $\leq 2$ minimal wages [22] and access to piped water (yes or no). The head of the family is represented by the individual with the highest family income. All questionnaires were previously tested by a pilot study, comprising 33 children and their caregivers. The pilot study participants were excluded from the main study.

\section{Data Analysis}

The statistical analysis was performed applying the STATA ${ }^{\circledR}$ Software (StataCorp LLC., Texas, USA) version 13.0. Firstly, the variables descriptive analyzes were carried out and the association between the quality of life and the independent variables was obtained by the Logistic Regression test. The method applied for the multivariate analysis was the Backward Stepwise. The independent variables with $\mathrm{p}<0.20$ in the unadjusted model were included in the adjusted analysis. In the adjusted analysis, values of $\mathrm{p} \leq 0.05$ were considered statistically significant. Results were expressed in Odds Ratio (OR) with 95\% confidence level. To evaluate the chosen model quality, the likelihood-ratio tests were applied, comparing the quality of the unadjusted and adjusted models, and the Hosmer-Lemeshow to verify the goodness of fit of the final model $[23]$.

\section{Ethical Clearance}

This project was approved by the Ethics Committee on Human Research of the Federal University of Santa Catarina (Protocol No. 902.633/2014) and by the City Department of Education. All participants signed informed consent before the study commencement. 


\section{Results}

Among the 1170 participating children, 1137 were included in the study, and 33 children were excluded due to the non-completion of the questionnaires (parental response rate 97\%). In the descriptive analysis, there was a predominance of 9 -year old (37.55\%) female $(57.61 \%)$ white children $(76.43 \%)$, in which the level of education of the head of household was $\geq 12$ years of study $(47.14 \%)$. Furthermore, most children presented family income $>2$ minimum wages $(51.80 \%)$, access to piped water $(97.01 \%)$ and overall good/very good health conditions $(85.40 \%)$. The sample characterization, according to the impact on the oral healthrelated quality of life and the demographic and socioeconomic variables, is shown in Table 1.

Table 1. Characteristics of the sample according to the oral health related quality of life impact and the demographic and economic characteristics.

\begin{tabular}{|c|c|c|}
\hline \multirow[b]{2}{*}{ Variables } & \multicolumn{2}{|c|}{ Impact on the Quality of Life } \\
\hline & $\begin{array}{c}\text { No Negative Impact } \\
\text { N (\%) }\end{array}$ & $\begin{array}{c}\text { With Negative Impact } \\
\text { N }(\%)\end{array}$ \\
\hline \multicolumn{3}{|l|}{ Gender } \\
\hline Male & $250(5.87)$ & $232(48.13)$ \\
\hline Female & $291(44.43)$ & $364(55.57)$ \\
\hline \multicolumn{3}{|l|}{ Children Skin Colour } \\
\hline White & $436(50.17)$ & $433(49.83)$ \\
\hline Non-White & $105(38.18)$ & $163(60.82)$ \\
\hline \multicolumn{3}{|l|}{ Children Age (Years) } \\
\hline 8 & $177(47.45)$ & $196(52.55)$ \\
\hline 9 & $205(48.01)$ & $222(51.99)$ \\
\hline 10 & $159(47.18)$ & $178(52.82)$ \\
\hline \multicolumn{3}{|c|}{ Head of Household Education } \\
\hline$\geq 12$ Years & $295(55.04)$ & $241(44.96)$ \\
\hline 9-11 Years & $100(42.37)$ & $136(57.63)$ \\
\hline 5-8 Years & $111(44.05)$ & $141(55.95)$ \\
\hline$\leq 4$ Years & $35(29.17)$ & $78(69.03)$ \\
\hline \multicolumn{3}{|l|}{ Family Income } \\
\hline$>2$ Wages & $295(50.08)$ & $294(49.92)$ \\
\hline$\leq 2$ Wages & $246(44.89)$ & $302(55.11)$ \\
\hline \multicolumn{3}{|l|}{ Piped Water } \\
\hline Yes & $527(47.78)$ & $576(52.22)$ \\
\hline No & $14(41.18)$ & $20(58.82)$ \\
\hline \multicolumn{3}{|l|}{ General Child Health } \\
\hline Very Good/Good & $467(4.09)$ & $504(51.91)$ \\
\hline Regular/Poor & $74(44.58)$ & $92(55.42)$ \\
\hline \multicolumn{3}{|l|}{ School Shift } \\
\hline Morning & $272(50.00)$ & $272(50.00)$ \\
\hline Afternoon & $269(45.36)$ & $324(54.64)$ \\
\hline
\end{tabular}

The CPQ scores and their respective domains are shown in Table 2. The domain with the highest variation was emotional well-being (0-16).

Table 2. Description of the mean and standard deviation, median, minimum and maximum, prevalence and percentage total scores of $\mathrm{CPQ}_{\text {s-10 }}$ domains.

\begin{tabular}{lccccc}
\multicolumn{1}{c}{$\mathbf{C P Q}_{\text {s-10 }}$ Domains } & Mean (SD) & Median & Minimum & Maximum & N (\%) \\
\hline CPQ $_{8-10}$ & $16.26(14.00)$ & 12 & 0 & 61 & $596(52.42)$ \\
Oral Symptoms & $5.57(3.54)$ & 5 & 0 & 15 & $649(57.08)$
\end{tabular}




\begin{tabular}{lccccc} 
Functional Limitations & $2.6(2.91)$ & 2 & 0 & 12 & $617(54.27)$ \\
Emotional Well-Being & $3.64(4.12)$ & 2 & 0 & 16 & $664(58.40)$ \\
Social welfare & $3.57(5.04)$ & 2 & 0 & 22 & $588(51.72)$ \\
\hline
\end{tabular}

Unadjusted and adjusted analyzes of the total CPQ and their respective domains are shown in Tables 3 and 4, respectively. Female children were 33\% (CI 95\% 1.04-1.69; p=0.019), being more likely to present a negative impact on the OHRQoL for the overall CPQ. In addition, it was observed that in the emotional and social well-being domains, female subjects were, respectively, $44 \%(\mathrm{p}=0.003)$ and $30 \%(\mathrm{p}=0.028)$ more likely to present a negative impact on the OHRQoL.

In the adjusted analysis, it was verified that non-white children reported a higher probability (46\%) (95\% CI 1.04-1.69; $\mathrm{p}=0.008)$ of presenting a negative impact on the OHRQoL when compared to white children for the overall CPQ. Considering functional limitation, emotional and social well-being, the non-white children are, sequentially, $57 \%(\mathrm{p}=0.002), 40 \%(\mathrm{p}=0.016)$ and $43 \%(\mathrm{p}=0.013)$ more likely to present a negative impact on the OHRQoL. Regarding the head of the household education level, it can be seen, from the total CPQ, that the probability of having a negative impact on the OHRQL was, respectively, 1.67 (95\% CI 1.212.27; $\mathrm{p}=0.001), 1.54(95 \%$ CI 1.14-2.09; $\mathrm{p}=0.005)$ and 2.59 (95\% CI 1.67-4.05; $\mathrm{p}=0.000)$ times higher in children whose caregivers had 9-11 years of study, 5-8 years of study and $\leq 4$ years of study compared to those whose caregivers had $\geq 12$ years of study. In addition, the four domains showed a negative impact on the OHRQoL $(\mathrm{p} \leq 0.05)$ for the variable head of household education.

Considering functional limitation, age was a protective factor for OHRQoL, and 9 to 10-year old children were, respectively, 26\% (CI 95\% 0.55-0.95; p=0.045) and 35\% (CI 95\% 0.49-0.90; p=0.008) less likely to present a negative impact on the OHRQoL when compared to 8-year old children.

The Hosmer-Lemeshow adjustment criteria and the likelihood ratio of the final CPQ total score models and their domains, respectively, presented: (I) total CPQ 0.9523 and 0.5712; (II) oral symptoms 1.00 and 0.2289; (III) functional limitations 0.7415 and 0.3955; (IV) emotional well-being 0.8193 and 0.6921 ; (V) social well-being 0.9880 and 0.5281 .

\section{Discussion}

The current research study confirmed the hypothesis that demographic and socioeconomic characteristics have a negative impact on the oral health-related quality of life in 8 to 10-year old children. The results showed that non-white skin color female subjects, who are the head of household, presents a low educational level, are associated with the negative impact on the OHRQoL. When analyzed by domains, age was also significantly associated. These results are relevant since they can help health care professionals and managers to plan and organize oral care policies driven-oriented to childhood, as well as the need to include socio-demographic variables in the adjustment models. Otherwise, false-negative results may be seen as the impact on the quality of life may only be influenced by socio-demographic characteristics without interference of oral conditions.

To better understand the oral health-related quality of life, it is necessary to understand the socioeconomic context in which the subject is inserted [9,10,24]. In addition, factors such as skin color, gender, family income and educational level, which stratify society and, thus, generate social disparities are important factors for assessing health conditions [25,26]. 
Table 3. Unadjusted analysis comparing the oral health related quality of life impact and the demographic and economic characteristics of schoolchildren.

\begin{tabular}{|c|c|c|c|c|c|c|c|c|c|c|}
\hline Variables & $\begin{array}{c}\text { CPQ }_{8-10} \\
\text { OR (IC 95\%) }\end{array}$ & p-value & $\begin{array}{c}\text { Oral } \\
\text { Symptoms } \\
\text { OR (IC 95\%) }\end{array}$ & p-value & $\begin{array}{l}\text { Functional } \\
\text { Limitations } \\
\text { OR (IC 95\%) }\end{array}$ & p-value & $\begin{array}{c}\text { Emotional } \\
\text { Well-Being } \\
\text { OR (IC 95\%) }\end{array}$ & p-value & $\begin{array}{l}\text { Social Well- } \\
\text { Being } \\
\text { OR (IC 95\%) }\end{array}$ & p-value \\
\hline \multicolumn{11}{|l|}{ Gender } \\
\hline Male & 1 & & 1 & & 1 & & 1 & & 1 & \\
\hline Female & $1.33(1.04-1.70)$ & 0.019 & $1.17(0.92-1.48)$ & 0.197 & $1.18(0.93-1.50)$ & 0.165 & $1.45(1.13-1.84)$ & 0.006 & $1.30(1.02-1.66)$ & 0.028 \\
\hline \multicolumn{11}{|l|}{ Children Skin Color } \\
\hline White & 1 & & 1 & & 1 & & 1 & & 1 & \\
\hline Non-White & $14.9(1.12-1.99)$ & 0.006 & $1.32(0.97-1.76)$ & 0.052 & $1.58(1.18-211)$ & 0.002 & $1.33(1.13-1.84)$ & 0.049 & $1.44(1.08-1.98)$ & 0.012 \\
\hline \multicolumn{11}{|l|}{ Children Age } \\
\hline 8 Years & 1 & & 1 & & 1 & & 1 & & 1 & \\
\hline 9 Years & $1.01(0.76-1.35)$ & 0.921 & $1.06(0.79-1.41)$ & 0.680 & $0.74(0.55-0.99)$ & 0.045 & $1.16(0.87-1.55)$ & 0.302 & $0.97(0.73-1.29)$ & 0.868 \\
\hline 10 Years & $0.98(0.72-1.33)$ & 0.921 & $0.84(0.62-1.13)$ & 0.261 & $0.66(0.49-0.90)$ & 0.009 & $1.18(0.87-1.60)$ & 0.287 & $0.98(0.73-1.32)$ & 0.897 \\
\hline \multicolumn{11}{|c|}{ Head of Household Education } \\
\hline$\geq 12$ Years & 1 & & 1 & & 1 & & 1 & & 1 & \\
\hline 9-11 Years & $1.67(1.22-2.29)$ & 0.001 & $1.45(1.00-1.92)$ & 0.018 & $1.40(1.02-1.92)$ & 0.033 & $1.45(1.06-1.99)$ & 0.020 & $1.85(1.35-2.53)$ & $<0.001$ \\
\hline 5-8 Years & $1.54(1.13-2.09)$ & 0.005 & $1.35(0.99-1.83)$ & 0.054 & $1.30(0.96-1.76)$ & 0.089 & $1.44(1.09-1.97)$ & 0.018 & $1.74(1.28-2.36)$ & 0.000 \\
\hline$\leq 4$ Years & $2.61(1.68-4.07)$ & $<0.001$ & $1.56(1.02-2.39)$ & 0.040 & $1.84(1.19-2.84)$ & 0.005 & $2.10(1.39-3.39)$ & 0.001 & $1.94(1.27-2.96)$ & 0.002 \\
\hline \multicolumn{11}{|l|}{ Family Income } \\
\hline$>2$ Wages & 1 & & 1 & & 1 & & 1 & & 1 & \\
\hline$\leq 2$ Wages & $1.24(0.98-1.58)$ & 0.096 & $1.07(0.85-1.36)$ & 0.535 & $1.18(0.58-2.40)$ & 0.639 & $1.07(0.84-1.36)$ & 0.554 & $0.97(0.77-1.24)$ & 0.856 \\
\hline \multicolumn{11}{|l|}{ Piped Water } \\
\hline Yes & 1 & & 1 & & 1 & & 1 & & 1 & \\
\hline No & $1.30(0.63-2.78)$ & 0.464 & $1.39(0.67-2.87)$ & 0.366 & $1.10(0.54-2.20)$ & 0.788 & $0.89(0.44-1.81$ & 0.757 & $1.09(0.54-2.20)$ & 0.807 \\
\hline \multicolumn{11}{|l|}{ General Child Health } \\
\hline Very Good/Good & 1 & & 1 & & 1 & & 1 & & 1 & \\
\hline Regular/Poor & $1.08(0.97-1.57)$ & 0.675 & $1.09(0.77-1.53)$ & 0.610 & $0.98(0.69-1.38)$ & 0.920 & $1.20(0.85-1.70)$ & 0.295 & $1.12(0.79-1.57)$ & 0.514 \\
\hline \multicolumn{11}{|l|}{ School Shift } \\
\hline Morning & 1 & & 1 & & 1 & & 1 & & 1 & \\
\hline Afternoon & $1.24(0.97-1.57)$ & 0.078 & $1.12(0.87-1.42)$ & 0.329 & $1.14(0.90-1.45)$ & 0.257 & $1.13(0.89-1.44)$ & 0.297 & $1.29(1.02-1.65)$ & 0.033 \\
\hline
\end{tabular}


Table 4. Adjusted analysis comparing the impact on the oral health-related quality of life and the demographic and economic characteristics of students.

\begin{tabular}{|c|c|c|c|c|c|c|c|c|c|c|}
\hline Variables & $\begin{array}{c}\text { CPQ }_{8-10} \\
\text { OR (IC 95\%) }\end{array}$ & p-value & $\begin{array}{c}\text { Oral Symptoms } \\
\text { OR (IC 95\%) }\end{array}$ & p-value & $\begin{array}{c}\text { Functional } \\
\text { Limitations } \\
\text { OR (IC 95\%) }\end{array}$ & p-value & $\begin{array}{c}\text { Emotional } \\
\text { Well-Being } \\
\text { OR (IC 95\%) }\end{array}$ & p-value & $\begin{array}{l}\text { Social Well- } \\
\text { Being } \\
\text { OR (IC 95\%) }\end{array}$ & p-value \\
\hline \multicolumn{11}{|l|}{ Gender } \\
\hline Male & 1 & & & & & & 1 & & 1 & \\
\hline Female & $1.33(1.04-1.69)$ & 0.019 & & & & & $1.44(1.13-1.84)$ & 0.003 & $1.30(1.02-1.66)$ & 0.028 \\
\hline \multicolumn{11}{|l|}{ Children Skin Color } \\
\hline White & 1 & & & & 1 & & 1 & & 1 & \\
\hline Non-White & $1.46(1.04-1.69)$ & 0.008 & & & $1.57(1.18-2.09)$ & 0.002 & $1.40(1.06-1.89)$ & 0.016 & $1.43(1.08-1.90)$ & 0.013 \\
\hline \multicolumn{11}{|l|}{ Children Age } \\
\hline 8 Years & & & & & 1 & & & & & \\
\hline 9 Years & & & & & $0.74(0.55-0.99)$ & 0.045 & & & & \\
\hline 10 Years & & & & & $0.66(0.49-0.90)$ & 0.008 & & & & \\
\hline \multicolumn{11}{|c|}{ Head of Household Education } \\
\hline$\geq 12$ Years & 1 & & 1 & & 1 & & 1 & & 1 & \\
\hline 9-11 Years & $1.66(1.21-2.27)$ & 0.001 & $1.44(1.05-1.97)$ & 0.021 & $1.40(1.02-1.91)$ & 0.032 & $1.45(1.06-1.99)$ & 0.019 & $1.85(1.35-2.52)$ & 0.000 \\
\hline 5-8 Years & $1.54(1.14-2.09)$ & 0.005 & $1.35(1.01-1.82)$ & 0.049 & $1.30(0.96-1.76)$ & 0.089 & $1.45(1.07-1.98)$ & 0.016 & $1.72(1.28-2.37)$ & 0.000 \\
\hline$\leq 4$ Years & $2.59(1.67-4.05)$ & 0.000 & $1.59(1.04-2.42)$ & 0.029 & $1.83(1.18-2.09)$ & 0.006 & $2.04(1.34-3.27)$ & 0.001 & $1.92(1.28-2.98)$ & 0.002 \\
\hline
\end{tabular}

OR: Odds Ratio; CI: Confidence Interval 95\%; *Adjusted by gender, skin color, age, educational level, family income, and school shift. 
In this study, there was an association between gender and oral health-related quality of life, recalling additional studies reported in the literature, which were conducted with children from different age groups [27-29]. In general, women tend to be more concerned about oral health [30,31], which may explain the greater report on the negative impact on the OHRQoL in female subjects compared to male subjects. Another important aspect to consider refers to the early concern of female subjects with facial aesthetics, since the domains that showed significant influences were the emotional and the social well-being.

Evidence has shown that black subjects and brown subjects are still a socially disadvantaged group due to, mainly, their low socioeconomic status accumulated over generations [32-35] Therefore, our findings demonstrated that non-white skin color might negatively influence the OHRQoL in schoolchildren, corroborating previous findings [35]. Another study, conducted with 11 to 14-year old children from public schools in Brazil, also confirmed the influence of skin color on the OHRQoL, in which the domains of emotional and social well-being were the most affected [20]. This information draws attention to the development of actions to fight against social inequality, especially in childhood, as the experience gained in this period may reflect the overall health and oral conditions in adulthood [10,13,14,36].

The parents' level of education also represents an important factor to be assessed in children's health, as educational inequalities in the family environment directly affect the individuals' physical and mental health, the behavior and the quality of life [37]. Our results showed that children whose caregivers had a low education level had a negative impact on all the quality of life domains related to oral health. Generally, subjects with higher educational level tend to present healthy oral hygiene and nutritional habits, as well as an increased demand for dental care [28,29,38]. Recent studies conducted in Southern Brazil with 3 to 5-year old children [4] and 15 to 19-year old adolescents of the state capitals and the Federal District in Brazil [39] corroborate our findings, showing that educational level can interfere in the OHRQoL in different age groups. In contrast to previous researches [21,26,35,37], family income was not significantly associated with the impact on the OHRQoL of the students.

Adequate sanitation conditions and access to piped water with public water fluoridation supply are directly related to children's oral health, being effective measures to reduce caries index and increase quality of life $[40,41]$. Brazilian cities with high HDI, including Florianópolis, benefit most from public fluoridation policies, covering both rich and poor areas [42,43], as shown in the present study, where almost all children had access to piped water supply. From this perspective, a possible explanation for the non-association of access to piped water with the impact on the OHRQoL in schoolchildren would be due to the low sample size of children not having access to public water coverage in this study.

Health inequalities have significant effects on several sectors of society, not just on ethical and theoretical issues. Negative impact on the quality of life caused by oral conditions still affect, in a greater extent, children in disadvantaged social position, contributing to the increase of social stratification [15]. Results appear to be generalizable to non-white children studying in public schools in Brazil, whose parents have a low level of education, which represents a significant portion of the population who need care, especially with oral health [20]. Therefore, considering all the information provided, our results are a warning to all health care professionals and managers considering the importance of having public policies for childhood, since the experience acquired during this period of life will reflect on adulthood, besides being an important step to achieve health equity. Also, this study helps the clinical dentist to identify the profile of children who have the greatest negative impact on oral health-related quality of life and those who would benefit from greater care in oral health. 
The present study presents some limitations and strengths. This is a cross-sectional study, not allowing causality estimation between the explanatory variables and the OHRQoL. Thus, longitudinal studies are necessary to better estimate the associations. In addition, data were collected only from public schools, not expanded to children private school, limiting the representation of the child population and generalization of the results. Strengths refer to the use of a representative sample and a validated instrument for assessing the oral health-related quality of life and the use of model fit criteria in statistical analyzes.

\section{Conclusion}

It is possible to verify relevant health inequalities such as low educational level of the head of household, female gender and non-white skin color presenting a negative impact on the oral health-related quality of life and their domains in 8 to 10-year old children.

\section{Authors' Contributions}

\begin{tabular}{|c|c|c|}
\hline JSM & (iD) $0000-0001-9011-9600$ & Conceptualization, Formal Analysis and Writing - Review and Editing. \\
\hline CM & (iD) $0000-0001-8033-055 \mathrm{X}$ & Conceptualization and Writing - Review and Editing. \\
\hline BSM & (iD) $0000-0002-0952-6899$ & Conceptualization, Investigation and Writing - Review and Editing. \\
\hline DK & (iD) $0000-0001-5692-8412$ & $\begin{array}{l}\text { Investigation, Data Curation, Writing - Original Draft Preparation and Writing - } \\
\text { Review and Editing. }\end{array}$ \\
\hline $\mathrm{MC}$ & (iD) $0000-0001-9936-7942$ & $\begin{array}{l}\text { Writing - Original Draft Preparation, Writing - Review and Editing, Project } \\
\text { Administration and Supervision. }\end{array}$ \\
\hline MB & (iD) $0000-0002-2835-9061$ & $\begin{array}{l}\text { Writing - Original Draft Preparation, Writing - Review and Editing, Project } \\
\text { Administration and Supervision. }\end{array}$ \\
\hline
\end{tabular}

\section{Financial Support}

Coordenação de Aperfeiçoamento de Pessoal de Nível Superior - Brasil (CAPES) - Finance Code O01 and Fundação de Amparo à Pesquisa e Inovação do Estado de Santa Catarina (FAPESC).

\section{Conflict of Interest}

The authors declare no conflicts of interest.

\section{References}

[1] Tsakos G, Allen PF, Steele JG, Locker D. Interpreting oral health-related quality of life data. Community Dent Oral Epidemiol 2012; 40 (3):193-200. https://doi.org/10.1111/j.1600-0528.2011.00651.x

[2] Buldur B, Guvendi ON. Conceptual modelling of the factors affecting oral health? related quality of life in children: a path analysis. Int J Paediatr Dent 2019; 30(2):181-92. https://doi.org/10.1111/ipd.12583

[3] Mcgrath C, Broder H, Wilson-genderson M. Assessing the impact of oral health on the life quality of children: implications for research and practice. Community Dent Oral Epidemiol 2004; 32(2):81-5. https://doi.org/10.1111/j.1600-0528.2004.00149.x

[4] Chaffee BW, Rodrigues PH, Kramer PF, Vitolo MR, Feldens CA. Oral health-related quality of life measures: variation by socioeconomic status and caries experience. Community Dent Oral Epidemiol 2017; 45(3):216-24. https://doi.org/10.1111/cdoe.12279

[5] Barasoul J, Soares J, Castro R, Giacomini A, Golçalves BM. Untreated dental caries is associated with reports of verbal bullying in children 8-10 years old. Caries Res 2017; 51(5):482-8. https://doi.org/10.1159/000479043

[6] Freire MCM, Corrêa-Faria P, Costa LR. Effect of dental pain and caries on the quality of life of Brazilian preschool children. Rev Saúde Pública 2018; 52:30. https://doi.org/10.11606/s1518-8787.2018052000093

[7] Dutra SR, Pretti H, Martins MT, Bendo CB, Vale MP. Impact of malocclusion on the quality of life of children aged 8 to 10 years. Dental Press J Orthod 2018; 23(2):46-53. https://doi.org/10.1590/2 177-6709.23.2.046-053.oar

[8] Ardenghi TM, Piovisan C, Antunes JL. Inequalities in untreated dental caries prevalence in preschool children in Brazil. Rev Saúde Pública 2013; 47(3):129-37. https://doi.org/10.1590/So034-8910.2013047004352 
[9] Blas E, Kurup AS (Eds). Priority Public Health Conditions Knowledge Network of the Commission on Social Determinants of Health. Equity, Social Determinants and Public Health Programmes. Geneva: World Health Organization; 2010.

[10] Sischo L, Broder HL. Oral health-related quality of life: what, why, how, and future implications. J Dent Res 2011; 90(11):1264-70. https://doi.org/10.1038/sj.bdj.2012.69

[11] Buss PM, Pellegrini Filho A. A saúde e seus determinantes sociais. Physis 2007; 17(1):77-93. https://doi.org/10.1590/S0103-73312007000100006

[12] Poulton R, Caspi A, Milne BJ, Thomson WM, Taylor A, Sears MR, et al. Association between children's experience of socioeconomic disadvantage and adult health: a life-course study. Lancet 2002; 360(9346):1640-5. https://doi.org/10.1016/So140-6736(02)11602-3

[13] Gülcan F, Ekbäck G, Ordell S, Lie SA, Astom AN. Inequality in oral health related to early and later life social conditions: a study of elderly in Norway and Sweden. BMC Oral Health 2015; 15:20. https://doi.org/10.1186/s12903-015-0005-y

[14] Listl S, Broadbent JM, Thomson WM, Stock C, Shen J, Steele J, et al. Childhood socioeconomic conditions and teeth in older adulthood: evidence from SHARE wave 5. Community Dent Oral Epidemiol 2018; 46(1):78-87. https://doi.org/10.1111/cdoe.12332

[15] Walt RG, Mathur MR, Ainda J, Bönecker M, Veturelli R, Gansky SA. Oral health disparities in children: a canary in the coalmine?. Pediatr Clin North Am 2018; 65(5):965-79. https://doi.org/10.1016/j.pcl.2018.05.006

[16] Instituto Brasileiro de Geografia e Estatistica. IBGE - cidades @. Available from: < https://cidades.ibge.gov.br/>. [Accessed on June 25, 2018]. [In Portuguese]

[17] Salas MMS, Ferreira-Vargas F, Ardenghi TM, Peres KG, Huysmans MC, Demarco, FF. Prevalence and associated factors of tooth erosion in 8 -12-year-old Brazilian schoolchildren. J Clin Pediatr Dent 2017; 41(5):343-50. https://doi.org/10.17796/1053-4628-41.5.343

[18] Barbosa TS, Vicentin MDS, Gavião MBD. Quality of life and oral health in children - Part I: Brazilian version of the Child Perceptions Questionnaire 8-10. Ciênc Saúde Coletiva 2009; 16(10):4077-85. https://doi.org/10.1590/S1413-81232011001100013

[19] Aimé NR, Van Wijk AJ, Maltz M, Varjão MM, Mestrinho HD, Carvalho JC. Dental caries, fluorosis, oral health determinants, and quality of life in adolescents. Clin Oral Investig 2016; 21(5):1811-20. https://doi.org/10.1007/s00784-016-1964-3

[20] Emanuelli B, Kucner AA, Ostapiuck M, Tomazoni F, Agostini B, Ardenghi TM. Racial differences in oral healthrelated quality of life: a multilevel analysis in Brazilian children. Braz Dent J 2015; 26(6):689-94. https://doi.org/10.1590/0103-6440201300478

[21] Salas MM, Nascimento GG, Huysmans MC, Demarco FF. Estimated prevalence of erosive tooth wear in permanent teeth of children and adolescents: an epidemiological systematic review and meta-regression analysis. J Dent 2015; 43(1):42-50. https://doi.org/10.1016/j.jdent.2014.10.012

[22] Martins MT, Sardenberg F, Vale MP, Paiva SM, Pordeus IA. Dental caries and social factors: impact on quality of life in Brazilian children. Braz Oral Res 2015; 29(1):1-7. https://doi.org/10.1590/1807-3107BOR-2015.vol29.0133

[23] Fávero LP. Análise de Dados: Modelos de Regressão com Excel ${ }^{\circledR}$, Stata $^{\circledR}$ e SPSS ${ }^{\circledR}$. Rio de Janeiro: Campus Elsevier; 2015. [In Portuguese]

[24] Marmot M, Bell R. Social determinants and dental health. Adv Dent Res 2011; 23(2):201-6. https://doi.org/10.1177/0022034511402079

[25] Von Rueden U, Gosch A, Rajmil L, Bisegger C, Ravens-Sieberer U. Socioeconomic determinants of health related quality of life in childhood and adolescence: results from a European study. J Epidemiol Community Health 2006; 60(2):130-5. https://doi.org/10.1136/jech.2005.039792

[26] Pappa E, Kontodimopoulos N, Papadopoulos AA, Niakas D. Assessing the socio-economic and demographic impact on health-related quality of life: evidence from Greece. Int $J$ Public Health 2009; 54(4):241-9. https://doi.org/10.1007/s00038-009-8057

[27] Locker D, Quiñorez C. To what extent do oral disorders compromise the quality of life? Community Dent Oral Epidemiol 2011;39(1):3-11. https://doi.org/10.1111/j.1600-0528.2010.00597.x

[28] Kumar S, Kroon J, Lallo R. A systematic review of the impact of parental socio-economic status and home environment characteristics on children's oral health related quality of life. Health Qual Life Outcomes 2014; 12(41):1-15. https://doi.org/10.1186/1477-7525-12-41

[29] Sun L, Wong HM, McGrath CP. The factors that influence oral health-related quality of life in 15-year-old children. Health Qual Life Outcomes 2018; 16(1):19. https://doi.org/10.1186/s12955-018-0847-5

[30] Peres, KG, Barros JD, Alsemi L, Peres MA, Barros, FC. Does malocclusioninfluence the adolescent's satisfaction with appearance? A cross-sectional study nested in a Brazilian birth cohort. Community Dent Oral Epidemiol 2008; 36(2):137-43. https://doi.org/10.1111/j.1600-0528.2007.00382.x

[31] Bulgareli JV, Faria ET, Cortellazzi KL, Guerra LM, Meneghim MC, Ambrosano GMB, et al. Factors influencing the impact of oral health on the daily activities of adolescents, adults and older adults. Rev Saúde Pública 2018; 52:44. https://doi.org/10.11606/S1518-8787.2018052000042 
[32] Bastos JL, Peres MA, Peres KG, Dumith SC, Gigante DP. Socioeconomic differences between self- and interviewerclassification of color/race. Rev Saúde Pública 2008; 42(2):324-34. https://doi.org/10.1590/S0034-89102008005000005

[33] Peres KG, Cascaes AM, Leão ATT, Côrtes MIS, Vettore MV. Sociodemographic and clinical aspects of quality of life related to oral health in adolescents. Rev Saúde Pública 2013; 47(Suppl.3):19-28. https://doi.org//10.1590/So034-8910.2013047004361

[34] Huang DL, Park M. Socioeconomic and racial/ethnic oral health disparities among U.S. older adults: oral health quality of life and dentition. J Public Health Dent 2015; 75(2):85-92. https://doi.org/10.1111/jphd.12072

[35] Shuch HS, Costa FS, Torriani DD, Demarco FF, Goettems ML. Oral health-related quality of life of schoolchildren: impact of clinical and psychosocial variables. Int $\mathrm{J}$ Paediatr Dent 2015; 25(5):358-65. https://doi.org/10.1111/ipd.12118

[36] Kabani F, Lykens K, Tak HJ. Exploring the relationship between adverse childhood experiences and oral healthrelated quality of life. J Public Health Dent 2018; 75(4):313-20. https://doi.org/10.1111/jphd.12274

[37] Marmot M, Allen J, Goldblatt P. Fair societies, healthy lives: strategic review of health inequalities in England post2010. London: The Marmot Review; 2010.

[38] Kragt L, Wolvius EB, Raat H, Vincent WVJ, Ongkosuwit EM. Social inequalities in children's oral health-related quality of life: the Generation R Study. Qual Life Res 2017; 26(12):3429-37. https://doi.org/10.1007/s11136-017-1679-1

[39] Alwadi MAM, Vettore MV. Are school and home environmental characteristics associated with oral health-related quality of life in Brazilian adolescents and young adults? Community Dent Oral Epidemiol 2017; 45(4):356-64. https://doi.org/10.1111/cdoe.12298

[40] Narvai PC, Frazão P. Saúde Bucal no Brasil: Muito Além do Céu da Boca. Rio de Janeiro: Fiocruz; 2008. [In Portuguese]

[41] Meyer J, Margaritis V, Mendelsohn A. Consequences of community water fluoridation cessation for Medicaid-eligible children and adolescents in Juneau, Alaska. BMC Oral Health 2018; 18:215. https://doi.org/10.1186/s12903-018-0684-2

[42] Frazao P, Narvai PC. Water fluoridation in Brazilian cities at the first decade of the 21 st century. Rev Saúde Pública 2017; 51(47):1-11. https://doi.org/10.1590/s1518-8787.2017051006372

[43] Silva JV, Machado FCA, Ferreira MAF. Social inequalities and the oral health in Brazilian capitals. Ciênc Saúde Coletiva 2015; 20(8):2539-48. https://doi.org/10.1590/1413-81232015208.12052014 